\title{
THE SOCIAL ORIGINS OF THE IRAN-IRAQ WAR
}

\author{
Thom Workman \\ Ph.D Candidate \\ Department of Political Science, and \\ Centre for International and Strategic Studies \\ York University \\ CISS Working Paper \#5 \\ March 1991 \\ Centre for International and Strategic Studies \\ York University \\ 4700 Keele Street, Downsview, Ontario, M3J 1P3
}




\section{Introduction}

The Iran-Iraq war has aptly been described as the Third World's first Great War. ${ }^{1}$ Conventional assessments of the costs of the war tend to focus upon lost oil revenues, declining GNPs, material destruction and even body counts. ${ }^{2}$ Estimates suggest that 1.2 million lives were lost in the war, with a further 2.2 million wounded. Up to 1.5 million people were uprooted by the fighting. At least 157 Iranian towns with populations of more than 5,000 were damaged or wholly destroyed during the war, and some 1,800 border villages were virtually wiped off the map. ${ }^{3}$ This concern with macroeconomic indicators or quantifiable measures of the war's destruction, however, all serve to obscure its dramatic social costs. The Iran-Iraq war profoundly affected the balance of social forces in both countries by eroding the social power of oppressed groups and classes and working exclusively to the advantage of the ruling regimes. These social costs are the greatest legacy of the Iran-Iraq war; its lingering social effects will be felt for many years to come.

This paper calls attention to the social costs of the war through an exploration of its social foundations. The Iran-Iraq war was largely engendered through the play of indigenous social forces. External actors had little direct role in its outbreak. In its most straightforward formulation, the IranIraq war may be understood as a dramatic political manifestation of extended social struggles endemic to both societies. We must contemplate this war, therefore, from the perspective of the Iranian and Iraqi social tapestries first and foremost. Analysis must unravel the complex class, communal and state dynamics at work in both countries. Through this society-centred approach we

l.

See discussion, for example, in: Samir al-khalil, Republic of Fear: The Politics of Modern Iraq, (University of California Press, 1989, p. 261. This paper was partially written with the assistance of archival materials from the Dayan Centre for Middle East and African Studies, Tel Aviv University, Israel. The author would also like to thank David Bell, Mike Burke, David Dewitt, Francois Fortier, Mark Neufeld, Helene Pellerin and Sandy Whitworth for helpful comments on earlier drafts.

For example, see: Bijan Mossavar-Rahmani, "Economic Implications for Iran and Iraq," in The Iran-Iraq War: New Weapons, Old Conflicts," eds. Shirin Tahir-Kheli and Shaheen Ayubi, (Praeger).

Statistics on human and village loses extracted from: Amir Taheri, The Cauldron: The Middle East Behind the Headlines, (Hutchinson, 1988), pp. 198-199; on refugees see: Martha Wenger and Dick Anderson, 'The Gulf War,' MERIP Middle East Report, 17:5 (September-October 1987), P. 25 . 
will arrive at a richer account of the origins of the Iran-Iraq war, a clearer explanation of its protracted course and why efforts to resolve it relatively quickly were largely unsuccessful, and foster a deeper appreciation of its stunning social costs.

\section{PART I: CONVENTIONAL APPROACHES TO WAR}

An approach to the causes of war which begins by addressing societal dynamics finds little precedent in international relations research. Most analysis can be summarized in terms of the 'three images' posited by Kenneth Waltz more than three decades ago: the individual, the state and the international anarchy. ${ }^{4}$ Related work on the causes of war has attempted to bridge or wed these various levels of analysis. ${ }^{5}$ Another trend in the literature examines the different spheres of human activity - technological, economic, political, legal and historical - and presents various combinations of these spheres as an explanation for international war. ${ }^{6}$ A final approach focuses upon different modes of social conflict - interpersonal, familial, organizational, societal etcetera - and then grafts its conclusions onto the realm of international relations. ${ }^{7}$

Absent from this inquiry has been the attempt to develop a theoretical understanding of the relationship between societal dynamics and war. There have been some important hints and suggestions in the literature, but these have not been accompanied by sustained theoretical refinement. Marxist debates on imperialism, for example, have drawn direct attention to the relationship between the international capitalist class and war. ${ }^{8}$ Similarly, Karl Polanyi's argument

4 Kenneth Waltz, Man, the State and War: A Theoretical Analysis, (Columbia University Press, 1959).

5 Glen H. Snyder and Paul Diesing, Conflict Among Nations: Bargaining, Decision Making 7 and System Structure in International Crises, (Princeton University Press, 1977).

b For example, see: Quincy Wright, A Study of War, (University of Chicago Press, 1964); Raymond Aron, Peace and War: Towards a Theory of International Relations, (Doubleday, 1969); Nazli Choucri and Robert C. North, Nations in Conflict: National Growth and International Violence, (San Francisco: Freeman, 1975).

? For example, see: J.S. Himes, Conflict and Conflict Management, (University of Georgia Press, 1982); Lawrence Kriesberg, Social Conflicts, (Prentice-Hall, 1982). 
concerning haute finance and World War I focused implicitly upon international class fractions and the development of war. ${ }^{9}$ Alternatively, Perry Anderson's Lineages of the Absolutist State explores the social basis of the relationship between the mercantilist outlook of the early modern era and the war prone character of the Absolutist states. ${ }^{10}$ The focus upon social and political development in the modernization literature resulted in a partial examination of the relationship between society, politics and international conflict. ${ }^{11}$ Finally, some of the literature examining the causes of the World War I addressed the relationship between communal conflict and war. ${ }^{12}$ Despite these exceptions, however, there has been no theoretical development around the social origins of war.

Recent research on the causes of war evinces a growing awareness of this theoretical lacunae. ${ }^{13}$ Undoubtedly, this scholarly agenda is informed by the fecund theoretical debate on the state and society which has taken place in the last two decades. ${ }^{14} \mathrm{We}$ see the effects of this debate within other

Karl Polanyi, The Great Transformation: the Political and Economic Origins of Our Time, (Beacon, 1957).

- Perry Anderson, Lineages of the Absolutist State, (London: Verso, 1979), chapter 1, especially pp. 31-7.

James N. Rosenau, International Aspects of Civil Strife, (Princeton University Press, 1964).

For example, see the debate between: Arno J Mayer, Internal Causes and Purposes of War in Europe, 18701956: A Research Assignment,' Journal of Modern History, 41 (September 1969); Peter Loewenberg, 'Arno Mayer's Internal Causes and Purposes of War in Europe, 1870-1956: An Inadequate Model of Human Behaviour, National Conflict and Historical Change,' Journal of Modern History, 42 (December 1979).

See: Martin Shaw, ed. War, State and Society, (Macmillan Press, 1984); Colin Creighton and Martin Shaw, eds., The Sociology of War and Peace, (British Sociological Association, 1987); Pat O'Malley, 'The Discipline of Violence: State, Capital and the Regulation of Naval Warfare,' Sociology, 22:2 (May 1988). In addition to the theoretical literature on the causes of war, there have been numerous regional analyses focusing upon state, society in international conflict. For example, see: Thomas P. Anderson, The War of the Dispossessed: Honduras and El Salvador, 1969, (Lincoln and London: University of Nebraska Press, 1981).

For an excellent survey of the developments in this literature see: Martin Carnoy, The State and Political Theory, (Princeton University Press, 1984). 
corners of the international relations field. The critiques of Immanuel Wallerstein's world systems analysis or of dependency theory, for example, have argued strenuously in favour of an explicit examination of society. ${ }^{15}$ Another corner of international relations research calls for a thorough reconsideration of the conventional conceptualization of the state in order to take adequate account of the structures of society. ${ }^{16}$ At least one theoretician in the field has explicitly raised the possibility of considering the 'state/society complex as the basic unit of international relations' in order to amplify societal level dimensions. ${ }^{17}$

From the vantage point of the fertile academic debate on the state and society this paper amplifies the social nature of international relations' most enduring subject matter: war. In flushing out the social dimensions of war we can contemplate a number of themes broadly stemming from the complex relationship between production and politics in society. One body of themes addresses conflict between classes, within fractions of the same class and between local and international classes. The relationship of the state to these configurations of social classes constitutes another important set of themes. Discussion in this regard has centred around the relative autonomy of the state from particular social classes and class fractions, and has increasingly argued that the state itself warrants considerable attention, but that the state does not escape the constraining pressures emanating from social forces in society. State institutions, in other words, are embedded in an array of contradictory social forces; state power is not aloof from the disposing and conditioning features

See: Colin Leys 'Underdevelopment and Dependency: Critical Notes,' Journal of Contemporary Asia, 7:1 (1977); Robert Brenner, The Origins of Capitalist Development: A Critique of Neo-Smithian Marxism,' New Left Review, 104 (July-August, 1977); Fernando H. Cardoso and Enzo Faletto, Dependency and Development in Latin America, (University of California Press, 1979).

R.B.J. Walker, 'The Territorial state and the Theme of Gulliver,' in International Journal, 39:3 (Summer 1984), 529-552; for a more recent comparison of two broad theoretical treatments of the state in relation to international relations analysis see: Fred Halliday, "State and Society in International Relations: A Second Agenda," Millennium: Journal of International Studies $16: 2$ (1987).

Robert Cox, 'Social Forces, States and World Orders: Beyond International Relations Theory,' in NeoRealism and Its Critics, ed. Robert O. Keohane, (Columbia University Press, 1986), p. 205. 
of the social canvas. ${ }^{18}$ The society-centred approach, therefore, explicitly addresses the state, but does so in the context of its constraining social base. A final set of themes draws attention towards non-class elements of social consciousness - such as ethnicity or gender - and frequently discusses these issues in terms of social power and social conflict. ${ }^{19}$

In the specific context of the Third World, moreover, a set of themes emerge that are broadly related to the rapid transformation of society in the face of the extension of capitalist relations of production in the Twentieth Century. ${ }^{20}$ One set of themes concerns the growth of new classes and their relationship with older established classes and the ruling classes. Extreme social dislocation and marginalization forms a second cluster of themes, and here we can consider the erosion of centuries-old customs and practices, the weakening of traditional social affiliations and the accompanying search for new forms of social identity, heavy migration to urban centres and the progressive deterioration of living conditions for large segments of the population. Extended social

The concept of state is exceptionally difficult to pin down. The view of this paper understands the state not so much as a subjective actor on the social canvas, although there is certainly an overarching coherence to state policies. A more fitting view of the state sees it as the principal locus of political power, as a structural ensemble rather than a subject, an instrument of political domination, and views state power as a complex social relation that reflects the changing balance of social forces in a determinate conjuncture.' See: Bob Jessop, 'Capitalism and Democracy: The Best Possible Political Shell,' in States and Societies, eds., David Held et al, (The Open University, 1983), especially pp. 272-5. Whenever the concept of 'regime' is employed in this paper, it refers to those individuals directly exercising state power.

Class and non-class analysts have frequently engaged in a sort of intellectual brinksmanship when assessing the political relevance of class issues. For a refreshing departure from this tendency see: Ronaldo Munck, The Difficult Dialogue: Marxism and Nationalism, (Zed Books, $1986)$.

For a treatment of some of these themes see: Harry Goulbourne, ed., Politics and State in the Third World, (Macmillan Press, 1983); James F. Petras et al, Class State and Power in the Third World, (Allanheld and Osman, 1981); Clive Y. Thomas, The Rise of the Authoritarian State in Peripheral Societies, (Monthly Review Press, 1984); Ernesto Laclau, Feudalism and Capitalism in Latin America,' New Left Review, 67 (1971). 
conflict constitutes another body of themes, with these conflicts being animated by both class and communal motifs. ${ }^{21}$ With these themes in mind we now turn to consider the social origins of the Iran-Iraq war.

\section{PART II: SOCIAL ORIGINS OF THE IRAN-IRAQ WAR}

At least five different explanations for the Iran-Iraq war have appeared in academic and journalistic commentary. The first account draws attention to the deeply rooted cultural enmity between Iran and Iraq and is premised upon a sense of incompatible and immanently hostile societies characterized in racial (Aryan and Semite), sectarian (Shi'i and Sunni), ethnic (Arab and Persian) or religious (secular and fundamentalist) terms. ${ }^{22}$ A second explanation calls attention to the megalomaniacal tendencies of Saddam Hussein: 'I think the whole question of how this war began,' Samir al-Khalil writes, 'resolves itself into what was passing through Saddam Hussein's mind.' This explanation finds confirmation in the name given to the war by Iraq - Qadisiyyat Saddam - and in the argument that Saddam Hussein was successful in extricating himself from any meaningful political constraints in Iraq. A third account focuses upon the declining Iranian hegemony in the Gulf region after the revolution. This regional power vacuum afforded the Ba'th regime in Iraq unique opportunities to extend its regional influence and enhance its Arab stature. A common fourth account of the war suggests that Iran was attacked simply because its inflammatory Shi'i rhetoric was fuelling revolutionary sentiments among the Shi'i population in Iraq. A final explanation focuses upon territorial disputes between the two states, especially those arising over the Shatt al-Arab waterway. The basic cut of this argument draws attention to Iraq's dislike of the 1975 Algiers Agreement which established the boundary of the Shatt al-Arab according to the thalweg (midchannel) principle rather than the eastern shoreline: 'Even if Iraq and Iran were homogeneous, even

The most explicit attempt to theorize about social conflict in Third World society may be seen in Edward Azar, 'Protracted Social Conflict: Ten Propositions,' International Interactions, (1984). 
if Iraq had no Shi'i problem,' stresses Daniel Pipes, 'the Shatt al-Arab issue would have sufficed to cause war to break out in $1980^{\prime} .^{23}$

Although each of these accounts of the war contains a kernel of truth, as a collection of explanations they remain woefully inadequate in that they fail to socially contextualize the Iran-Iraq war. They afford little attention to the complex social dynamics at work within either country. Frequently, as in the case of the cultural explanations or the focus upon Hussein's psyche, these accounts of the war entirely overlook the complex array of social forces within Iraq. Similarly, even when attention is given to social divisions within society, as in those explanations addressing the Shi'i threat to the Ba'th regime in Iraq, little additional effort is made to understand Shi'i politics in terms of other dynamics and struggles within Iraqi society. Again, explanations which call attention to territorial disputes such as the Shatt al-Arab or to regional aspirations in the Gulf generally overlook the relationship of these factors to dynamic class and communal developments within either society. These accounts tend to separate the 'causes' of the Iran-Iraq war from the broader social dynamics unfolding within each country. In other words, as real as the war may be, it is not understood as a social reality. By default, these musings carelessly reify most facets of the war and thereby fail to understand its social costs, especially in terms of the extension of oppressive relations within Iran and Iraq. Explanations which neglect the social foundations of the Iran-Iraq war are, at best, partial accounts; at worst, the interventionist parturitions of discussions which fail to appreciate the social realities underlining war may be politically naïve and grossly misguided.

In the broadest possible terms we begin to detect the origins of the Iran-Iraq war by understanding the interaction between 'forces from the international environment and specific local processes and structures with their own specific logic' throughout the Twentieth Century. ${ }^{24}$ Only the broadest sketches of these developments may be adumbrated here. ${ }^{25}$ Political and economic imperatives in the early twentieth century determined that the state boundaries of the two countries would not be

Daniel Pipes, 'A Border Adrift: Origins of the Conflict', in The Iran-Iraq War: New Weapons, Old Conflicts, ed. Shirin Tahir-Kheli and Shaheen Ayubi, (Praeger, 1984), p. 21. Pipes is particularly critical of those accounts of the war which over-emphasize the cultural dimensions of the war.

See introductory discussion in Talal Asad and Roger Owen, eds., Sociology of Developing Societies: The Middle East, (Monthly Review Press, 1983), pp. 7-8. Social and Economic Development in the Arab Gulf, (St. Martin's Press, 1980). 
drawn in accordance with the multi-ethnic character of the region. Both Iran and Iraq were gradually integrated into the world economy and capitalist relations of production have been continually extended throughout both countries. The central economic sector catalyzing these transformations was hydrocarbon extraction and processing. The Iraqi and Iranian states were instrumental in facilitating the processes of economic transformation in both countries, and played increasing roles in the economy throughout the post-war period. Agrarian reforms in both countries largely resulted in deteriorating production and spawned increased migration into the urban centres. In terms of class structure there was the growth of working classes, new intermediate classes including salaried professionals, intellectuals and teachers and a small indigenous bourgeoisie. At the same time the political and social influence of the clerical and traditional petty bourgeoisie undulated under the pressures of economic modernization; in the case of the landed classes agrarian reforms caused their political influence to wane significantly. ${ }^{26}$ It is commonplace to observe that the favourable effects of the particular path of socio-economic development in Iran and Iraq were highly skewed in favour of thin segments at the top of society while increasing privation and social marginalization plagued the largest segments of the population. Major urban centres - especially Tehran and Baghdad - have acquired squalid slums under the pressures of urban migration as individuals search for a better life in the towns and cities.

Political development was not commensurate with socio-economic change in either country throughout most of the post-war period. In the case of Iraq, political control of the state remained somewhat fluid between 1958 and 1968 until the Arab Ba'th Socialist Party successfully resecure control. Iran, from 1953 up to the Islamic revolution, was ruled by the Phavlavi monarchy. In both countries, through a combination of shear wealth via the oil rent and well-honed repressive apparatuses, the ruling regimes were able to acquire considerable degrees of conjunctural autonomy from any particular social class. Conventional political parties and alternative political organizations were systematically attacked and rendered largely ineffective. Consequently, while the socioeconomic transformations of Twentieth Century Iran and Iraq created new social expectations and

26

The most exhaustive study of class formation in Iran is: Ervand Abrahamian, Iran Between Two Revolutions, (Princeton University Press, 1982). The most thorough study of class formation in Iraq remains: Hanna Batatu, The Old Social Classes and the Revolutionary Movement in Iraq, (Princeton University Press, 1978). For a provocative review of Abrahamian's work see: Eric Hooglund in MERIP Reports, 13:3 (March-April 1983); and for Batatu's work see articles by Tom Nieuwenhuis, Marion Farouk-Sluglett, Peter Sluglett and Joe Stork in MERIP Reports, no. 97 (June 1981). 
demands among classes and groups in both societies, the political avenues to address these demands were progressively closed off. Increasingly, political opposition manifested itself in the form of direct attacks against the regime and in protracted struggles in the countryside. The disjuncture between the political sphere and the socio-economic sphere in both Iran and Iraq has produced extremely volatile political conditions for the ruling regimes. In the case of Iran, of course, the incongruity between the political and socio-economic worlds fostered the sustained struggles throughout the latter half of the 1970s that culminated in the Islamic revolution.

It is within this transformed social canvas that we can detect the origins of the Iran-Iraq war. The socio-economic transformations of the Twentieth Century set in motion distinct social and political struggles that culminated in the three crucial political dimensions most closely associated with the outbreak of the war: the inflamed Islamic rhetoric emanating from Iran in the aftermath of the revolution; the alarmed Ba'thi response in the face of a perceived Shi'i uprising in Iraq; and the Iraqi Ba'th attempts to secure and stabilize oil export revenues. Expressed differently, the political aspirations and vulnerabilities that impelled both regimes to war for almost eight years are stained by the structural disjunctures between the political and socio-economic spheres in Iraqi and Iranian society, disjunctures that in turn are fundamentally signatured by the class and communal struggles engendered by the broad socio-economic transformations in these societies throughout the Twentieth Century. This paper now examines the social basis of the Iranian revolution, the Shi'i struggles in Iraq and attempts by the Baghdad regime to secure oil export revenues.

\section{The Iranian Revolution}

In the aftermath of the Mossadeq downfall in 1953 the Shah consolidated power with considerable assistance from SAVAK. ${ }^{27}$ The Shah's political strategy of wooing traditional classes, including the bazaaris and the landed class, and containing the modern classes was weakened by an 
economic crisis in the early 1960s and American pressures for land reform. With restlessness increasing among the subordinate classes the Shah implemented a series of policy reforms collectively known as the White Revolution. Central among these reforms was the Land Reform Law of 1962 which successfully broke the backs of the traditional landed classes, a development which reflected the growing influence of the modern, urban classes in Iranian society. In the economic sphere, the Shah attempted to modernize the Iranian economy through import-substitutionindustrialization and attempts to untie the Iranian dependence upon oil. As the Shah moved to supplant the traditional economy he came into directly conflict with the bazaar class of merchants and traders, a conflict that would eventually prove devastating for the monarchy. Attempts at economic modernization were also accompanied by agricultural reforms that continually failed to meet production expectations.

On the eve of the Iranian revolution the urban classes included the bourgeoisie, propertied middle classes including the bazaaris, smaller entrepreneurs and some 90,000 clergymen, a salaried middle class of over half a million and a large working class. In the countryside there were absentee farmers, independent farmers and khoshneshin - agricultural labourers -numbering at one million families. ${ }^{28}$ Although the monarchy catered to the requirements of the upper class in Iran, through the oil rent and the well honed police state it developed considerable autonomy from direct class influence. Increasingly, in the repressive political atmosphere under the Shah, socio-economic demands failed to receive an adequate political hearing. The grievances of all subordinated classes against the regime were heightened with the economic crisis of the mid-1970s, and the stability of the monarchy became increasingly tenuous. This social disenchantment with the monarchy was exacerbated by the untimely formalization of a one-party system by the Shah, a move interpreted by the opposition as a brazen promulgation of political closure in Iran. At the same time unique political openings were created through the momentary weakening of the Shah's repressive state. Increasing social agitation and protest from the modern and traditional middle classes, the working classes and the urban poor culminated in a six month generalized strike in 1978. Ultimately, these struggles, along with a loss of support within the army rank and file and a loss of confidence in Washington combined to overthrow the monarchy. ${ }^{29}$

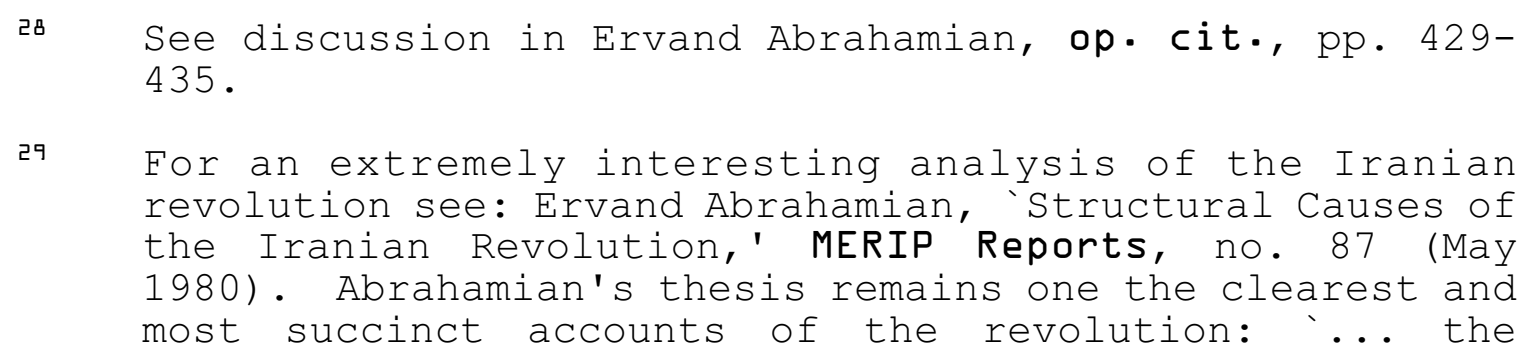


The revolution was for the most part urban based and primarily employed political confrontation in its struggle against the regime. An extremely diverse collection of classes and groups had coalesced against the Shah. Despite the diverse collection of groupings, however, the Islamic character of the revolution is indisputable. A handful of reasons underline this ideological colouring. Most importantly, there was an organic link between the bazaaris and the clergy. The matrix of the revolutionary ideology in Iran lies in the reaction of the clerics and the bazaaris to the socioeconomic trends of the Twentieth Century. Both social classes felt increasingly frustrated and threatened by the secularizing and modernizing trends under the Shah. The bazaaris in particular were directly attacked by the Shah through such policies as the anti-profiteering campaign of the mid-1970s. This class found ideological leadership in Islam, and the alliance with the clergy would ultimately be secured by Islam's 'sanction of private property'. ${ }^{30}$ In turn, the traditional petty bourgeoisie formed the primary social base of the ulama.

Other factors combined to insure that the revolution would have a distinctly Islamic hue. As an integral element of Iranian culture, Islam naturally structured social grievances, especially in view of the lack of alternative opportunities for political expression, and in particular it provided an ideational blueprint for social frustrations with the monarchy: 'The Islamic ideology was important insofar as it gave form,' Farideh Farhi observes, 'to already existing grievances against a foreigndominated, repressive state. ${ }^{31}$ In organizational terms as well, the mosque network was crucial for communication and mobilization within the repressive political atmosphere under the Shah. The combined effect insured that the religious network would become a highly politicized venue. 'The mosque became a key rallying place for people to express grievances and hold mourning ceremonies,' Misagh Parsa writes, 'which were not only religious occasions but also provided

failure of the Pahlavi regime to make political modifications appropriate to the changes taking place in the economy and society inevitably strained the links between the social structure and the political structure, blocked the channelling of social grievances into the political system, widened the gap between new social forces and the ruling circles, and, most serious of all, cut down the few bridges that had in the past connected traditional social forces, especially the bazaars, with the political establishment.'

30
Ahmad Ashraf, 'Bazaar and Mosque in Iran's Revolution,' MERIP Reports, 13:3 (March-April 1983), p. 16.

Farideh Farhi, op cit, p. 103. See also: Abrahamian, op cit, pp. 535-6. 
opportunities for political expression. ${ }^{132}$ Moreover, the charismatic figure of Khomeini provided a rallying point for the revolution. As one scholar notes: 'Khomeini is to the Islamic Revolution what Lenin was to the Bolshevik, Mao to the Chinese, and Castro to the Cuban revolutions. ${ }^{133}$ The Islamic character of the Iranian revolution, therefore, cannot be solely understood as a manifestation of any intrinsically animating qualities that Shi'ism may possess. Rather, the links between the clerics and the bazaaris and the reaction of both these classes to the threats of secularization and modernization, the organizational importance of the mosque network in the repressive political atmosphere, the cultural importance of Islam and the charismatic figure of Khomeini all combined to insure that the revolution would have a distinctive Islamic hue.

In the immediate aftermath of the revolution the Provisional Revolutionary Government exercised formal power. The PRG tended to view the revolution exclusively in terms of a transformation of political structures, and they naturally sought to promote the private sector. Ultimately, the PRG proved incapable of addressing heightened class conflicts spurred on by rising social expectations among peasants, workers and the urban masses. ${ }^{34}$ De facto state power devolved into the hands of the Islamic fundamentalists. With a diverse range of potential opposition including the secular left as well as the liberal-moderates, the ascendancy of the clerics would certainly not go unchallenged. ${ }^{35}$ The clergy, with strong links to the popular organizations that spontaneously arose during the revolution, was able to consolidate its power through massive political mobilization. This mobilization was nurtured through a form of theocratic populism wherein Islam provided the nourishment and cohesion for a political project that was essentially manipulative in character, which concerned itself with the interests of the 'masses', and which adopted a clearly xenophobic character. ${ }^{36}$ The struggle of the 'ulama to consolidate its power and extend its class hegemony

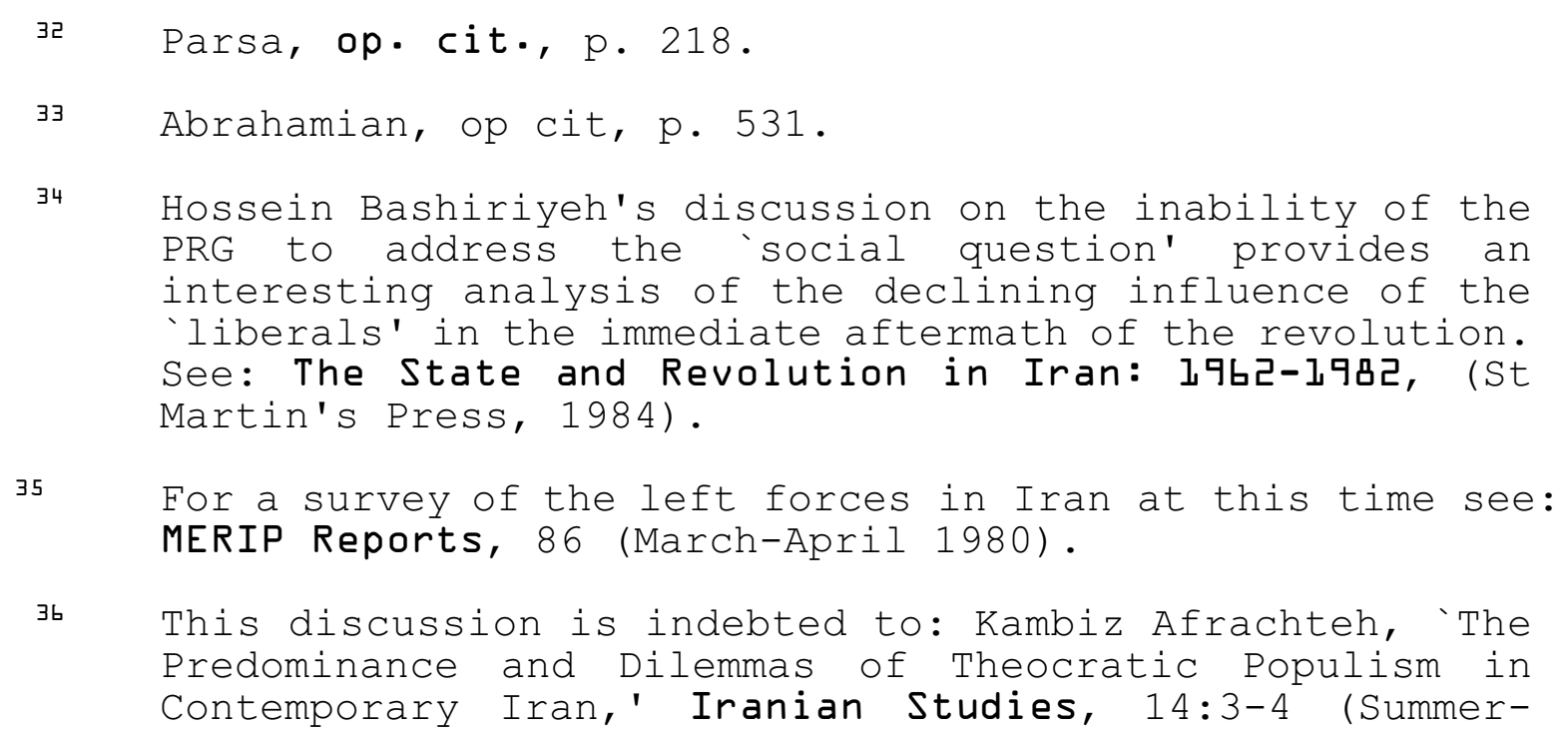


would ensure that the Islamic motifs and symbols would be exploited to the fullest extent possible. In the end, Islamic themes blended with this-worldly struggles to produce the new Islamic Republic.

The conflicting and erratic nature of Iran's foreign policy in the immediate aftermath of the revolution reflected the intense internal power struggle. ${ }^{37}$ The steady ascendancy of the clerics, however, increasingly brought coherence to Iranian foreign policy, and it is here that we see the germination of the aggressive campaign against Iraq. By itself, the ascendancy of the clerics and the Islamic character of the revolution go a considerable distance in explaining the external agitation by the Iranian regime. Among the ideologues, for example, the Islamic narratives of overthrowing impious states (futah) were undoubtedly operative. ${ }^{38}$ Nevertheless, the theocratic populist project adopted by the clerics insured that Islamic themes would be trumpeted far and wide. Stated simply, there was no cultural imperative unfolding in the Gulf region in the early 1980s. The theocrats were equally motivated by the somewhat more temporal concern of consolidating their grip on the state. As a result, Iran was exporting revolution as part of the process of consolidating the revolution at home. External agitation became an integral element in the politics of refraction whereby popular frustrations were adroitly grafted onto Satanic foes. In the case of Iraq the aggressive campaign took numerous forms including radio broadcasts, direct acts of sabotage and support for its Shi'i groups. The campaign evoked extreme concern among the Iraqi Ba'th regime.

\section{The Iraqi Response}

The alarmed Iraqi reaction to the Iranian campaign forms the second crucial political dimension relevant to the outbreak of the war. This reaction, however, cannot be properly understood apart from the pattern of socio-economic evolution of Twentieth Century Iraq. The social structure of contemporary Iraq is the product of the gradual insertion of the three vilayets of Basra, Baghdad and Mosul into the world economy. ${ }^{39}$ The first phase of this insertion revolved around agricultural exports and led to the formation of a latifundista style of agricultural production with the rise of a

\section{Autumn 1981).}

37

38

39
See discussion in: John W. Limbert, Iran: At War with History, (Westview Press, 1987), pp. 135-142.

See discussion of the idea of futah in: Bernard Lewis, The Political Language of Islam, (University of Chicago Press, 1988).

This discussion draws extensively upon Joseph Stork, 'Class, State and Politics in Iraq,' Power and Stability in the Middle East, ed. Berch Berberoglu (Zed Books, 1989). 
landowning class, a peasant class and a mercantile bourgeoisie. ${ }^{40}$ In the second phase of this insertion, however, the oil industry has largely charted the course of Iraqi economic and social development. The development of an urban working class resulted in the formation of the Iraqi Communist Party by $1941 .{ }^{41}$ By the late 1970 s there was a working class, traditional and modern middle classes (including an abnormally large pool of salaried state workers as the regime attempted to absorb as much of the surplus workforce as possible), rural agricultural workers and a smaller industrial bourgeoisie. ${ }^{42}$ These class developments paved the way for conflicts that resulted in a considerable fluidity in Iraqi politics throughout the post-war period, a fluidity broadly guided on the one hand by the struggle of middle classes and class fractions to assert their class hegemony and on the other hand by struggle between them and the political expressions of the working class, especially the ICP. These political struggles culminated in the second accession of the Arab Ba'th Socialist Party to power in 1968.

A crucial development in post-war Iraqi politics has been the ability of the Iraqi state to acquire considerable autonomy from any particular social class. The matrix of this development has been the access of the state to huge oil revenues, fully secured with the nationalization of the Iraqi Petroleum Company in the spring of 1972. One important political implication of these revenues lies in the development of a soberingly repressive political order. The repressive apparatus of the state includes the Amn (Internal State Security), the Estikhbarat (Military Intelligence) and the very powerful Mukhabarat (Party Intelligence) along with the regular army and the party militia. ${ }^{43}$ The effectiveness of these state institutions has resulted in the liquidation of alternative political organizations within Iraq. This process began in earnest in the post-1968 period and was essentially completed by the late $1970 \mathrm{~s}$. On the legal terrain, for example, failure to declare affiliation with alternative political parties was punishable by death, while declarations of alternative affiliations

The term latifundista is borrowed from the Latin American case which summarizes the experience of large landholdings, few landowners and a large and increasingly impoverished peasant class.

These developments receive their best documentation in Hanna Batatu, The old Social classes and the Revolutionary Movement in Iraq (Princeton University Press, 1978).

See: Joe Stork, 'Class, State and Politics in Iraq', in Power and Stability in the Middle East, ed., Berch Berberoglu (Zed Books, 1989). security apparatus see: al-Khalil, op. cit., chapter 1. 
were not terribly wise. The net effect was the creation of a political vacuum both at the organizational level and in terms of the progressive narrowing of public discourse and debate to the pale of the Ba'thi world view. Indeed, one interpretive history of contemporary Iraq has gone as far as to speak of the 'death of politics' within the country. ${ }^{44}$

The second political implication of this wealth has been the overwhelming influence of the Ba'th in Iraqi politics. Notwithstanding the petty bourgeois character of the Arab Ba'th Socialist Party in Iraq in 1968, oil revenues have by and large allowed the political direction of the Ba'th to proceed according to its own logic, a logic fundamentally guided by the imperative of regime maintenance. Although the Ba'th regime rests upon an extremely narrow social footing, no other political group in Iraqi society has been able to acquire the resources to crack this Ba'thi monopoly. Until the mid1970s the Iraqi Communist Party stood the best chance of wrestling meaningful concessions from the regime. The Progressive Patriotic National Front of 1973 between the Ba'th and the Iraqi Communist Party, however, proved to be an extended cooptive strategy on the part of the Ba'th, and by 1979 the once powerful ICP was essentially driven underground. ${ }^{45}$ As a result of the repressive political atmosphere and the extensive Ba'thization of Iraqi society, political control in post-1968 Iraq has increasingly evolved onto the Ba'th, and within the party onto Saddam Hussein and his ruling coterie.

Consequently, although the transformed structure of Iraqi society created a wide range of socioeconomic and political interests as it evolved in the post-war period, the means for addressing them were systematically choked off during the 1960s and 1970s. In the case of labour, for example, the regime removed its right to strike. The Ba'th, of course, attempted to deal with these grievances by penetrating peasant co-operative societies, trade unions, women's organizations or youth organizations. The political agenda here, however, was one of manipulation in order to render the activities of these groups more commensurate with Ba'thi needs and interests. At the same time the state created its own interest groups in order to promote Ba'thi goals. One such body was the General Federation of Iraqi Women, an organization primarily oriented towards furthering Ba'thi breeding requirements. ${ }^{46}$ The obliteration of alternative mediums of political expression in Iraq was

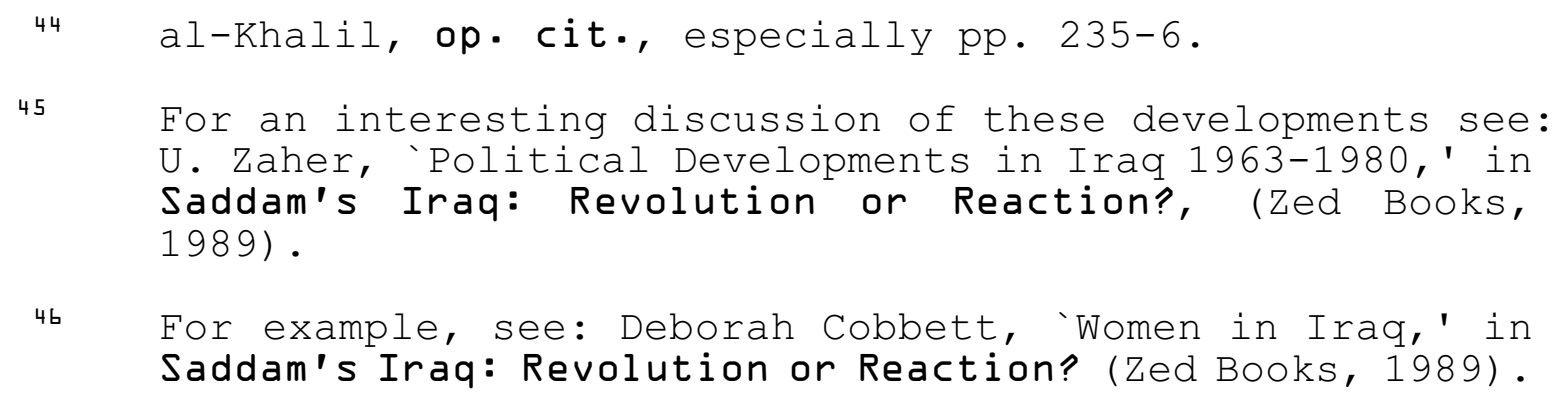


tantamount to a form of disempowerment on the part of aggrieved groups and classes within Iraqi society.

This specific political and social conjuncture helps to explain the rise of a Shi'i opposition within Iraq during the late 1970s. On the one hand, the traditional clerical class was reacting both to its loss of material support and its loss of prestige in the face of the social changes engendered by the modernizing and secularizing tendencies of the Ba'th. As one writer straightforwardly noted: 'The ulama were losing ground and declining in prestige and material influence. ${ }^{17}$ The initial manifestations of this restlessness could be seen in the rise of the Fatimiyyah in 1964. By the late 1970s two Shi'i parties could be identified: ad-Da'wah al-Islamiyyah (the Islamic Call) and alMujahidin (the Muslim Warriors). Moreover, Islamic motifs around legitimacy and political obedience undoubtedly helped to give form to existing social grievances arising out of the extreme poverty and political marginalization of the masses. ${ }^{48}$ Specifically, from its formative stage onwards, Shi'ism was identified with 'the rebellion and struggle of the downtrodden and oppressed in the Islamic empire, and its doctrines accommodated their aspirations for social justice and equality. ${ }^{19}$ Shi'ism clearly had the capacity, as evident in Iran, to structure and animate social struggles against the Ba'th. Finally, Iraq's socio-economic evolution guaranteed that serious grievances against the regime would arise. Development throughout the post-war period in Iraq was accompanied by extreme social dislocation, particularly as rural reforms eroded living conditions in the countryside and prompted massive migration into the urban centres. These rapidly shifting demographics contributed to the rise of deplorable living conditions in the towns and cities. One such settled area around greater Baghdad, Madinat ath-Thawrah, an area where the ICP once garnered much of its support, proved to be one of the main bases of Shi'i support in the late 1970s. Originally designed to house no more than 300,000 people, its population inflated to 1.5 million. The slums of Madinat ath-Thawrah have been identified as 'the stronghold of heroes' in militant Shi'i literature.

By the late 1970s the processionals of Islam became important political stages. Demonstrations in Shi'i towns and Shi'i neighbourhoods of Baghdad significantly increased as did clashes with the police. At one such procession in 1977 between Najaf and Karbala the crowds aggressively chanted:

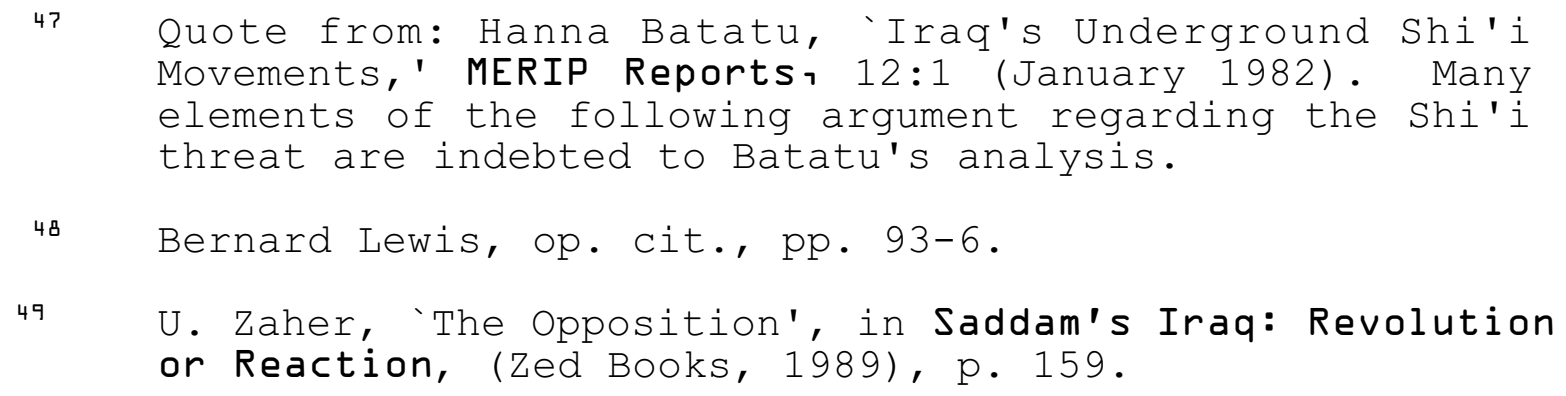


'Saddam, remove your hand! The people of Iraq do not want you!' Guerilla attacks upon the police, the Ba'th Party and the popular army were stepped up. The Iraqi regime responded with tarhib (terror) on the one hand and targhib (the proverbial carrot) on the other. ${ }^{50}$ In the spring of 1980 Baqir as-Sadr (the most learned of Iraq's ayatullahs) was executed along with his sister and other prominent Shi'i figures. At the same time, however, Hussein generously dispensed funds to support mosque constructions. Both strategies were designed to avoid a repeat of the Iranian revolution, and underscored the gravity of the threat from the perspective of the Ba'th regime.

The Ba'thi susceptibility to a Shi'i revolution was rooted in the socio-economic and political developments unfolding in Iraq, developments that were accelerated in the post-war period, including the massive migration to the urban areas, the protective posture of the clerical class and the repressive political atmosphere under the Ba'th regime. By 1980, the revolutionary potential of Shi'ism was taken seriously by the Iraqi regime. The aggressive rhetoric and practices emanating from revolutionary Iran clearly exacerbated this potentially explosive situation. Ultimately, Iraq would be motivated to move against the nascent regime in Iran in order to remove this external threat. It is exceptionally difficult to assess, however, whether this threat emanating from Iran would have sufficiently compelled the Ba'th regime to attack. Nonetheless, the Iraqi decision to invade would be affected by a third political dimension related to the outbreak of the war: the struggle by the Ba'th regime to secure and stabilize oil revenues.

\section{Oil and the War}

The struggle to secure and stabilize oil revenue constitutes the third political dimension relevant to the outbreak of the war. It would be incorrect to simply argue that the oil interests in Iraq caused the war. What is more plausible, however, is that the importance of oil revenues created special vulnerabilities for the Ba'th regime, and this manifested itself in regional policy designed to reduce these vulnerabilities. Two frequently identified aspects of the war - Hussein's struggle for regional hegemony and to a lesser extent the dispute over the Shatt al-Arab water way - are related to these vulnerabilities. As discussed above, the dramatic increase in oil revenues insulated the Ba'th regime from any particular social class. The revenues created a wider array of options for the state in dealing with social classes and potentially explosive issues. Periodic increases in wages, for example, allowed the regime to avoid direct confrontations with the working class. The campaign of mosque constructions was implemented for similar effect. Again, the absorption of surplus labour into the notoriously inefficient public service sector of the Iraqi state is similarly geared. The 
distribution of tens of thousands of television sets and cash donations to Kurdish families that were forcibly removed from the border regions in the north provides yet another example of the important political functions oil revenues. ${ }^{51}$ These cooptive strategies were utterly dependent upon oil money. Through them the regime attempted to contain the subordinate classes and groups, at least to some extent, by selectively responding to their demands. One collective commentary on the Iraqi situation summed up the situation well: 'The regime could finance this political base-building thanks to the almost unlimited funds available for all kinds of educational, welfare, industrial and other capital projects. ${ }^{52}$ Stated baldly, oil revenues were crucial for regime maintenance.

By itself, these oil revenues would provide the regime with a strong impulse to secure and promote this source of income. But it is equally clear that dynamic class developments within Iraq provided another motive for the regime. More than simply creating the conditions for the expansion of capitalism in Iraq, the Ba'thi state became the lifeline for the parasitic fraction of the Iraqi bourgeoisie which includes contractors, brokers, bureaucrats and speculators. ${ }^{53}$ By 1975, for example, there were 2,788 contractors officially registered with the state. The fraction of the bourgeoisie remains thoroughly dependent upon the state, fully relying upon the state sponsored development projects to advance its interests, and frequently receiving generous concessions from the state by being allowed to bypass tax and labour laws. This parasitic bourgeoisie, in turn, forms an important base of support for the regime. State sponsored development, therefore, created important new fractions among the capitalist class within Iraq during the 1970s. This particular form of capitalism in Iraq naturally retains a keen interest in maintaining oil revenues.

Iraq, however, has perennially faced a situational vulnerability with respect to oil revenues, a vulnerability that went far beyond normal fluctuations in the world market price for crude oil. In the late 1970s Iraq had three oil exporting outlets. The first was the less profitable terminals off the Iraqi coastline in the Gulf. The second and third were pipelines through Syria and through Turkey. Iraq, therefore, had many of the vulnerabilities of a landlocked country. The pipelines were the Achilles heel of the Iraqi economy, rendering the Ba'th regime vulnerable to the undulations of international

51

52

53

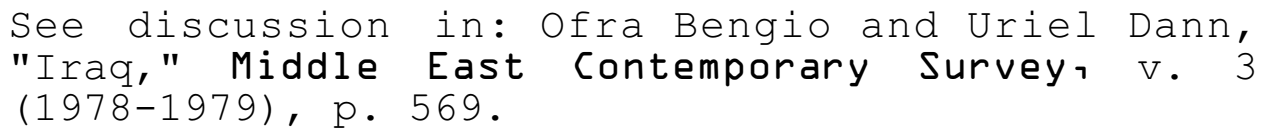

See discussion in: Ofra Bengio and Uriel Dann, "Iraq," Middle East Contemporary Survey, V. 3 (1978-1979), p. 569.

Marion Farouk-Sluglett, Peter Sluglett and Joe Stork, 'Not Quite Armageddon: Impact of the War on Iraq,' MERIP Reports, 14:6/7 (July-September 1984), p. 29.

This discussion draws extensively upon: 'Isam al-Khafaji, 'The Parasitic Base of the Ba'thist Regime, ' in Saddam's Iraq: Revolution or Reaction, (Zed Books, 1989). 
political conditions. Indeed, the flow of Iraqi oil via the Syrian pipeline was subject to numerous interruptions prior to the war. The turmoil in Iran provided the Ba'th regime with a unique opportunity to assert its presence in the Gulf and enhance its prestige within the Arab world. Greater influence in the Gulf region and entire control of the Shatt al-Arab waterway could only raise Iraq's Arab stature. Regional stature and influence within the Arab community is essential to enhancing its influence over OPEC production and pricing policy. Hence, the regime felt that political events in Iran afforded it a unique opportunity to overcome its situational vulnerability.

\section{The Move to War}

The Iraqi attack upon Iran was motivated by the Shi'i disturbances and by its situational vulnerability to fluctuating oil revenues. Iran figured prominently in both of these aspects, intentionally aggravating the Shi'i situation in Iraq on the one hand and standing in the way of a more prominent Iraqi role in regional oil affairs on the other. The appearance of a unique opportunity in the guise of internal Iranian disarray, especially within the military, would sufficiently tip the scales in favour of direct Iraqi intervention. After an escalation in border skirmishes between the two countries through the summer of 1980, Iraq launched a full-scale invasion of Khuzistan on September 22, 1980.

All indications suggest that Hussein thought the war would be very short. Within a month the Iraqis had seized Khorramshahr and by the end of 1980 they had penetrated up 20 miles of the entire Iranian front. Within six months of the start of the war, however, Iranian counter-offensives were beginning to take their toll upon the Iraqi army. Two years after the initial invasion the war had for the most part shifted onto Iraqi soil. As the war passed through its third and fourth years it displayed all the features of a deadlocked, attrited and drawn out affair. ${ }^{54}$ Attacks on oil tankers and direct mutual missile assaults on Iraqi and Iranian towns did little to change this bleak scenario. Attempts to end the war by the Islamic Conference Organization, the Organization of Non-aligned countries, the UN Secretariat General and the Warsaw Pact countries all failed. Unilateral initiatives, notably

For two accounts of the first half of the war see: Dilip Hiro, 'Chronicle of the Gulf War,' and Ghassan Salameh, 'Checkmate in the Gulf War,' MERIP Reports, 14:6/7 (July - September, 1984); also see: Efraim Karsh, 'The IranIraq War: A Military Analysis,' Adelphi Papers, no. 220 (London: International Institute for Strategic Studies, 1987 ). 
by Algeria, met with similar success. These failures prompted one commentator to sum up the efforts of the international community as 'routine and in the main futile. ${ }^{155}$

\section{PART III: THE SOCIAL DIMENSIONS OF ENDING THE IRAN-IRAQ WAR}

In accounting for these failures to bring the war to an end we must again ponder the behaviour of both regimes from the perspective of the societies in which they are embedded. As with the research on the causes of war, the diffuse and wide-ranging conflict management/resolution literature generally fails to consider the prolongation and termination of war in terms of the wider characteristics of society. One stream of this literature examines the problem of institutionalizing peaceful approaches to conflict management. ${ }^{56}$ Another large pool of research periodizes conflict into crisis management $^{57}$, the problem of conflict escalation ${ }^{58}$, and those processes - especially bargaining and negotiation - aimed at terminating or resolving conflict. ${ }^{59}$ A body of literature has

Uriel Dann, 'The Iraqi-Iranian War,' Middle East Contemporary Survey, 8 (1983-1984), eds., Haim Shaked et al, p. 186 .

Johan Galtung, 'Institutional Conflict Resolution,' Journal of Peace Research, 2:4 (1965); An even earlier discussion of the problem of institutionalizing adequate procedures of conflict management can be found in Kenneth Boulding, Conflict and Defense: A General Theory, (New York: Harper and row, 1963), chapter on conflict resolution.

Michael Brecher, 'International Crises and Protracted Conflicts,' International Interactions, 11:3 (1984); Daniel Frei, ed., Managing International Crises, (Sage Publications, 1982); Ole R. Holsti, 'Historians, Social Scientists and Crisis Management: An Alternative View,' Journal of Conflict Resolution, 24:4 (December 1980).

For the still classic treatment of this problem see: Richard Smoke, War: Controlling Escalation, (Harvard University Press, 1977).

The literature on bargaining and negotiation is endless. For a few samples of this literature see: Samuel B. Bacharach and Edward J., Lawler, Bargaining: Power, Tactics and Outcomes, (San Francisco: Jossey-Bass, 1981); S.D. Bailey, How Wars End, 2 volumes, (Oxford University Press, 1982); Jacob Bercovitch, 'An Analysis of Negotiation as a Successful Approach to International Conflict Management: Egyptian-Israeli Negotiations at Camp David,' Crossroads, 17 (1985), 83-106; J.S. Murray, 
been erected around the vast array of social, political and military instruments available to manage and resolve conflict, including peacekeeping forces ${ }^{60}$ and confidence and security building measures. ${ }^{61}$ Considerable attention has also been given to the activities and roles of conflict managers including international organizations and other third parties, regional powers, middlepowers and superpowers. ${ }^{62}$ While the importance of certain social dimensions is suggested by

\footnotetext{
'Understanding Competing Theories of Negotiation,' Negotiation Journal, 2:2 (1986); Paul R. Pillar, Negotiating Peace: War Termination as a Bargaining Process, (Princeton, N.J.: Princeton University Press, 1983); Howard Raiffa, The Art and Science of Negotiation, (New York: Academic Press, 1982); Thomas C. Schelling, 'An Essay on Bargaining,' The American Economic Review, 46:3 (June 1956).
}

b०

Moskos, Charles C., Jr., Peace Soldiers: The Sociology of United Nations Military Force, (Chicago: University of Chicago Press, 1976); Rikhye, Indar Jit, The Theory and Practice of Peacekeeping, (London: C. Hurst and Company, 1984); Eide, Asbjorn, Peace-Keeping and Enforcement by Regional Organizations,' Journal of Peace Research, 3 (1966).

bl For an exhaustive list of the various aspect of conflict management instruments see: Walter Isard and Christine Smith, Conflict Analysis and Practical Conflict Management Procedures, (Ballinger, 1983); For a survey of confidence building measures see: Karl N. Lewis and Mark Lorell, 'Confidence-Building Measures and Crisis Resolution: Historical Perspectives,' Orbis, 28:2 (Summer 1984); for some interesting discussions of confidencebuilding measures see: Josef Binter, 'Approaches to Security and Confidence-Building: Concepts of Peace Research,' Peace and the Sciences, 1 (1987), 42-49; Peter Stania, Some Points of Departure for ConfidenceBuilding,' Peace and the Sciences, 2 (1987), 30-5.

be This body of literature is very wide-ranging. For example, see: Oran Young, The Intermediaries: Third Parties in International Crises, (Princeton University Press, 1967); Ernest B. Haas, Conflict Management by International Organizations, (General Learning Press, 1972); Chris Mitchell, Peacemaking and the Consultants Role, (Farnborough, Hants and Gower, 1981); Raimo Vayrynen, 'Is There a Role for the United Nations in Conflict Resolution?', Journal of Peace Research, 22:3 (1985); Michael Harbottle, 'The Strategy of Third Party Intervention in Conflict Resolution,' International Journal, 35:1 (Winter 1979-80); Jacob Bercovitch, Social 
occasional references to social and political instruments of conflict management, analysis of conflict resolution is not undertaken from the perspective of societal dynamics.

As argued here, however, the keys to understanding the prolongation of the war between Iraq and Iran are precisely these elements of society which have conventionally been downplayed in conflict resolution research. That is, the protractedness of the Iran-Iraq war is related to political struggles arising out of the wider social canvases of both countries. In Iran especially, the war played a pivotal role in the difficult process of revolutionary consolidation by the clerics. Similarly, in Iraq, although the outward willingness to end the war appeared much sooner, its prosecution still managed to carry political advantages for the Ba'th regime.

\section{The War and Iran}

The ascendency of the clerics in the revolutionary aftermath would only serve to bring the contradictory social base of the revolution into sharper focus, a social base that was itself responsible for deep conflicts within the new regime. Broadly speaking, the line of the Imam faction promoted a more radical platform capable of appealing to the population as a whole, while the more conservative Hojjatiyeh faction maintained a certain fidelity to the traditional petty bourgeoisie and other propertied interests. Conflict over the such issues as the nationalization of foreign trade would reveal these divergent lines within the regime. ${ }^{63}$ Gradually, the outlook of the more conservative faction would prevail. As the revolution entered the Thermidor, the engineering of social consciousness would take on a crucial importance; political and social themes capable of transcending class and group consciousness - the peasants, the working class, women and the urban poor - would be needed in order to maintain support for the regime.

The difficulties in maintaining a wide base of support for the regime in view of the inherently conflictual socio-economic outlooks of post-revolutionary Iranian society were evident to some observers relatively quickly. Ervand Abrahamian, for example, presciently dwelt upon one likely effect of a direct invasion of Iran: ‘. . . the clergy are unlikely to find another public enemy as unpopular as the shah against whom they can rally the whole population - unless, of course, a foreign

Conflict and Third Parties: Strategies of Conflict Resolution, (Boulder, Colorado: Westview Press, 1984); Robert Lyle Butterworth, 'Do Conflict Managers Matter? An Empirical Assessment of Interstate Security Disputes and Resolution Efforts, 1945-1974,' International Studies Quarterly, 22:2 (June 1978). 
enemy invades the country and threatens the existence of the entire nation. ${ }^{164}$ Enter Iraq! The clerics would prove most adept at exploiting the war in order to establish their class hegemony. The Ba'th invasion provided the clerics with the axiomatic common enemy; xenophobic themes were fully utilized in order to politically mobilize and secure support for the theocratic regime. The regime extolled Iraq as the embodiment of all that was antithetical to the Islam; the tenets of the theocratic populist project were brutally confirmed. For the 'ulama, the war became nothing less than the war against the 'Great Satan' incarnate. In short, through the invasion the Islamic character of the revolution was honed and sharpened and this process undoubtedly served to provide a degree of social cement for the deeply fractured Iranian society. The defense of Islam, by implication, became the defense of the theocratic regime. ${ }^{65}$

The war provided an umbrella like pretext for the various facets of revolutionary consolidation in the Islamic Republic. First, the war assisted in legitimizing the thorough and often brutal repression of opposition forces. At the outset of the revolution a number of potential opposition groups existed and could have possibly seized state control or at least hindered the political project of the clerics. They fell into four different streams including the secularists (with a number of political parties), the left groups, including the Fedayeen and the well organized and powerful Mojahedin, and the regionalist/nationals which included most prominently the Kurds numbering 2.5 million. This latter group also included the Arabs, Azerbaijani Turks, the Qashqa'i Turks, and the Turkomanis. ${ }^{66}$ The war was exercised in conjunction with a full-scale assault on the Iranian Kurdish insurgency. The peshmergas were subject to similar sensational methods of warfare as Iraq, including human-wave assaults, and the Kurdish people of Iran, estimated at over 10 per cent of the population, were subject to Shi'i propaganda, detention, forced resettlement and outright massacre. ${ }^{67}$

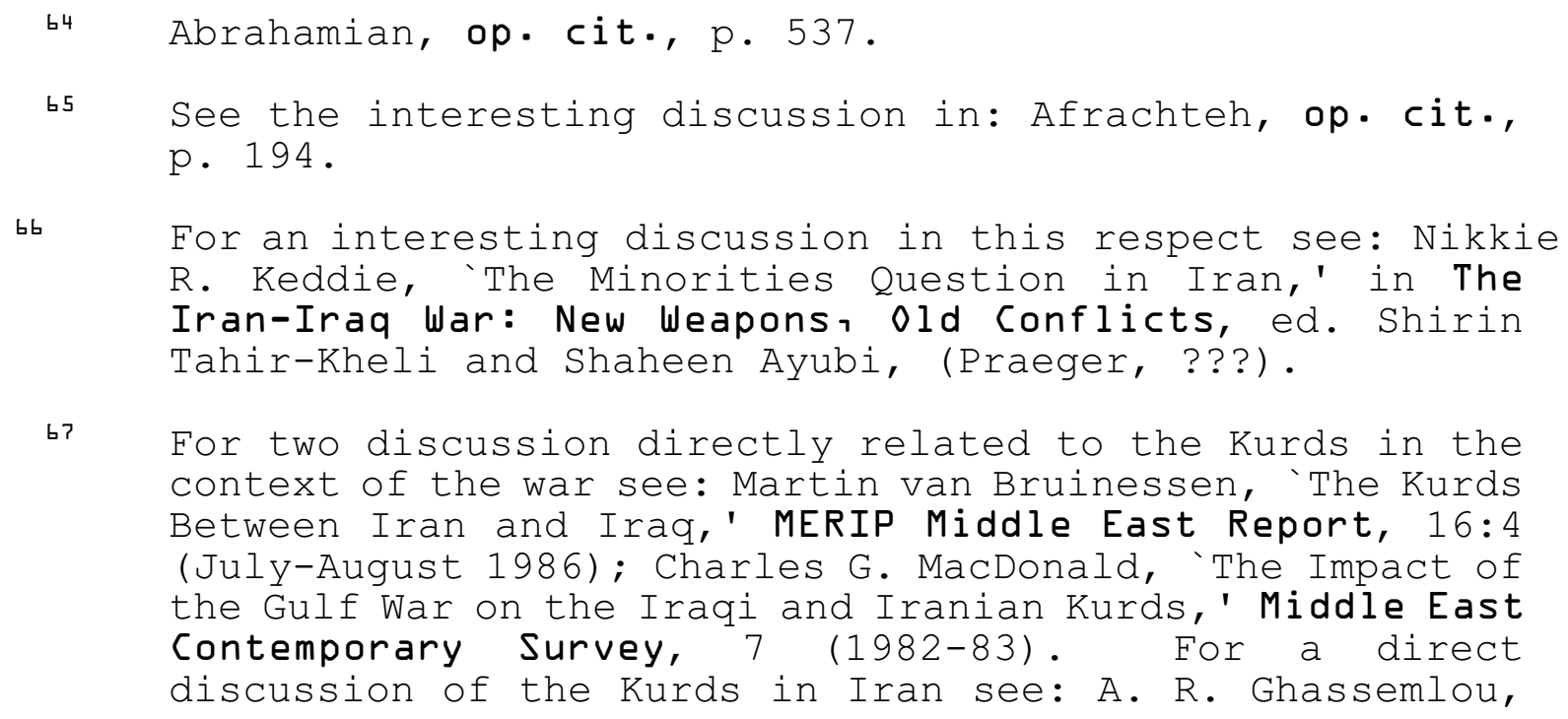


Finally, the regime faced varying degrees of opposition from women. Oppressive conceptions of gender in Iran were reinforced with the general desecularization of Iranian society. Women were forced, for example, to observe the hejab and were encouraged to preoccupy themselves with the 'precious function of motherhood, rearing alert and active human beings. ${ }^{168}$ On the whole, the opposition's effectiveness was 'adversely affected by the war. ${ }^{169}$ By the third year of the Revolution most of the opposition to the regime had been exiled or simply extirpated. In 1981 the Council of National Resistance was established in Paris. This broad coalition included the Mujahidin, the Kurdish Democratic Party, Bani-Sadr and the National Democratic Front. By 1983 it became clear that even those left-wing parties that had initially cooperated with the regime, such as the Tudeh, were virtually wiped out. The intolerant atmosphere of the regime received its most poignant confirmation with the growing influence of the stridently anti-communist Hojjatiyeh faction among the ruling group.

The war also assisted the regime in expanding and securing control over crucial postrevolutionary institutions and consolidating control over the traditional apparatus of the state. Figuring most prominently here was the pasdaran. As a counterbalance to the army, the Revolutionary Guards grew to the point that they outnumbered the Regular Army. The establishment of the Ministry of Revolutionary Guards confirmed the permanency of this feature of the post-revolutionary state's coercive apparatus. A further element of the post-revolutionary security apparatus was the basijis (Mobilization of the Oppressed) which tended to draw younger recruits. Both the Basijis and the Pasdaran provided the theocrats with important counterbalancing forces against the army, especially in the earlier stages of the revolution when Bani-Sadr's close relationship to the regular army was arousing suspicion within the IRP. ${ }^{70}$ Moreover, at least four different intelligence groups were charged with the responsibility for controlling the regular army by policing it, handling agitprop, identifying cells of opposition and controlling suspected military personnel. The ranks of these organizations, moreover, tended to draw heavily among the young,

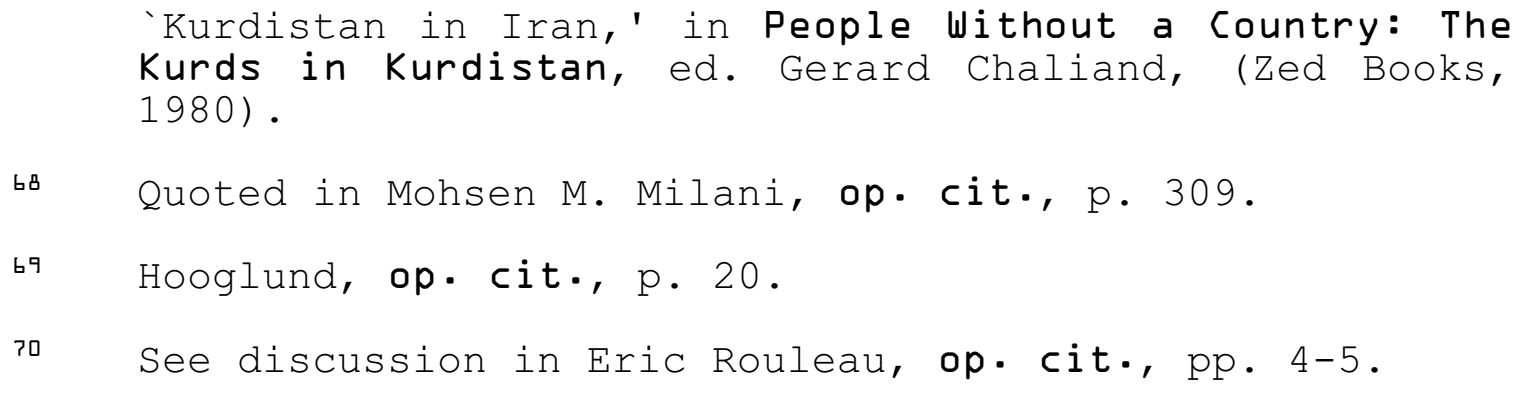


urban poor and lower middle classes which had the effect of securing support for the regime. ${ }^{71}$ The civilian counterpart to the pasdaran - the Jahad-e Sazandeghi or Reconstruction Crusade - was another popular organization commandeered by the IRP in order to concretize rural support for the regime. ${ }^{72}$ Within the legislative apparatus clerical control was assured by institutional changes such as establishment of a clerical body known as the Shura (Council of Guardians) which can veto parliamentary legislations. ${ }^{73}$ More generally, the war was used as a pretense for extensive purges within the state bureaucracy and within the various media. Again, the war was enlisted to rationalize contentious policy. ${ }^{74}$ It also served as a pretext to further the desecularization of Iranian society. To this end, changes within the educational system, including textbook revisions and the removal of teachers and students not sufficiently Islamic, were also undertaken. Criminal, civil and commercial statutes were re-written under the supervision of Shi'i jurists. By the summer of 1982 all secular laws were deemed null and void.

Above and beyond the elimination of political opposition, the war was used as a pretext for the repression of any potentially disruptive social action. Most notable here was the stark suppression of worker activity in the aftermath of the revolution using whatever economic, political, ideological or military means were necessary. ${ }^{75}$ In order to combat worker militancy the regime set up labour sections within the Pasdaran and the Basijis. Although the working class may have been the 'battering ram' of the revolution, the regime expressed early and immediate opposition to their basic form of workers' organization known as the shura. ${ }^{76}$ The regime continued to Islamicize the especially note 10 . Crusade and Class Conflict in Iran,' MERIP Reports, 13:3 (March-April 1983), especially p. 11 and p. 15.

See discussion of this body in the context of economic policy divisions within the regime in: Fred Halliday, 'Year IV of the Islamic Republic,' p. 4.

See discussions in: Eric Rouleau, 'The War and the Struggle for the State,' MERIP Report, no. 98. (JulyAugust 1981).

Analysis here is extracted from: Assef Bayat, 'Workers' Control After the Revolution,' MERIP Reports, 13:3 (March-April 1983). 
workplace through the establishment of Islamic associations which stood in opposition to the independent shuras and which acted as vehicles for the establishment of maktabi management (Islamic management). Maktabi management acquired prevalence with the removal of Bani-Sadr and the waning influence of 'liberals'. The regime proclaimed work as a religious duty: 'To work itself,' Khomeini admonished cement workers in Tehran, 'is a jihad (crusade) for the sake of God; God will pay for this jihad - the jihad of labour which you [workers] are carrying out inside the barricade of the factory. ${ }^{177}$

The continuation of the war on Iran's part can thus be attributed to the distinct advantages that it brought to the theocrats. The war provided the regime with a unique opportunity to consolidate its power through the elimination of political opposition, the extension of control of revolutionary institutions and the containment of any disruptive social behaviour. Equally importantly, the war allowed the theocrats to appeal to unifying social themes in a deeply fractured post-revolutionary society. As long as the war brought these advantages for the clerics, efforts to end it would not gather significant momentum within ruling circles.

\section{The War and Iraq}

Saddam Hussein's confidence at the outset of the war led him to attach impossible conditions to the first United Nations ceasefire resolution of September 28, 1980. With the turning tides of the war in the next two years, however, Hussein became more and more inclined to end it. By the end of 1982 Iraq was clearly prepared to search for a compromise solution to end the war. ${ }^{78}$ Moreover, Iraq's attempts to internationalize the war, especially through tanker attacks, were designed to bring further international pressure on Iran after initial efforts to draw the war to a close had failed. Despite the military setbacks, however, there were contradictory pressures operating on Saddam Hussein, pressures that would ultimately allow Iraq to live with the war as long as requisite revenues for its prosecution could be maintained. Indeed, minimal financing was sustained through two means. First, the regime was able to maintain some oil revenues. Attacks by Iran on Iraq's southern port facilities, along with the closing of the Syrian pipeline, had caused a drastic decline in Iraq's oil revenues in the early years of the war. Nonetheless, the regime was able to partially recover. In 1985, for example, Iraq opened an oil pipeline into Saudi Arabia, and it was also able to export oil overland by truck to the Jordanian port of Aqaba. Secondly, the Ba'th regime supplemented its

\footnotetext{
7 Bayat, op. cit., p. 23.

78 See discussion, for example, in: Glen Balfour-Paul, 'The Prospects for Peace,' in The Iran-Iraq War, ed. M.S. ElAzhary, (Croom Helm, 1984).
} 
revenues through the provision of large quantities of cash, credit and oil exchanges, especially from Saudi Arabia and Kuwait.

Despite these problems, however, the war afforded the regime with unique opportunities to extend its political control. The war allowed the regime to engage in its own populist strategies, and in the context of the Ba'thi struggle for social consciousness the effects of this opportunity should not be underestimated. When the war was carried into Iraqi territory, Hussein's position as defender of the Arab nation was fully exploited. Bombed-out shops in the city of Basra were strewn with posters hailing Hussein as 'the second great conqueror of the Persian Army. ${ }^{179}$ The 'Iraqi man' became the national symbol, transcending any class, religious or ethnic fractures of Iraqi society. The Arab/Persian dimension to the war was trumpeted loudly by the regime, as clearly evident in the name given by Iraq to the war - Quadisiyyat Saddam - which harkens back to the Arab/Persian struggles of the seventh century. In short, the Ba'th regime skilfully held the war out in the cause of the Arab nation. ${ }^{80}$

As was the case in Iran, the war also provided a pretext for continuing the repressive politics of the Ba'th regime. The regime used the war to justify repressive labour practices and to extend the oppression of Iraqi women: 'Baghdad is plastered with anti-contraception posters exhorting mothers to breed for their country. ${ }^{181}$ The regime was also able to fill its labour shortages through Egyptian migrant labour numbering at a staggering 1 million workers. ${ }^{82}$ Aside from providing a much needed pool of labour, migrant workers insured that labour disturbances will be kept to a minimum. The regime also abolished the state-controlled federation of trade unions and rescinded the labour code of 1970. Perhaps the clearest use of the 'war pretext' lies in the relationship between the Ba'th regime and the Kurdish insurgency. The regime engaged in an extensive counter-insurgency

79

81

82

80
See discussion in: Marion Farouk-Sluglett, Peter Sluglett and Joe Stork, 'Not Quite Armageddon: Impact of the War on Iraq,' op. cit., p. 24.

See discussion in Stephen R. Grummon, 'The Iran-Iraq War: Islam Embattled,' The Washington Papers, 92 (1982), chapter 3 . 
campaign against the Kurds, a campaign that included massive relocation programmes, sanitation zones along its Turkish and Iranian borders and brutal practices such as chemical warfare. ${ }^{83}$

The utter annihilation of any formal political opposition within Iraq helped to insure that vocal protests against the war would be muted. Equally importantly, the war itself caused fragmentation among the underground opposition movement in Iraq, especially between the Patriotic Union of Kurdistan, the Kurdish Democratic Party and the Iraqi Communist Party. ${ }^{84}$ At the same time, the regime did its best to insulate its social base, the bourgeoisie, from the negative effects of the war, especially as state revenues ran thin. ${ }^{85}$ Evidence suggests that private sector expansion in Iraq continued unabated during the war. ${ }^{86}$ In the end, the war provided the regime with opportunities to extend its political grip over Iraq society. Understandably, the removal of the war pretext was of serious concern to the Ba'th regime as the likelihood of a ceasefire became evident in 1988. As one commentator on the Iraqi scene wrote: 'After the ceasefire Saddam Hussein is no longer able to claim he is defending the homeland or use the war as a justification and smokescreen for mass repression and terror in Iraq. ${ }^{187}$

\section{Termination of the War}

Hence, although the war certainly bore heavy material and human costs, it brought clear political advantages to both regimes. The deep fractures in both societies could be glossed over in the interests of the war effort, and the benefits would accrue almost exclusively to the regimes exercising power. The social corollary of this reality, however, is the equally clear extension of oppressive relations in both countries. The social power of subordinate classes and groups - especially the rural and urban poor, the Kurds, the working classes and women - slipped appreciably. The social and political effects of this slippage will last well beyond the conclusion of the fighting.

For an excellent account of the Kurds in Iraq up to the war see: Ismet Sheriff Vanly, 'Kurdistan in Iraq,' in People Without a Country: The Kurds and Kurdistan, ed. Gerard Chaliand, (Zed Books, 1980).

4 Isam al-Khafaji, 'Iraq's Seventh Year: Saddam's Quart d'Heure?,' op. cit., pp. 37-8.

See discussion in: 'Isam al-Khafaji, 'Iraq's Seventh Year: Saddam's Quart d'Heure?', Middle East Report, (March-April 1988), pp. 38-39.

Sluglett et al, op. cit., pp. 29-30.

Muhsin et al., op. cit., p. 240. 
By the late 1980s, almost a decade after the war had erupted, a few crucial points cannot be overlooked. In Iran, the process of revolutionary consolidation was essentially completed. By 1988, the regime faced 'no internal threat to its power. ${ }^{188}$ In an important sense, the war had outlived its usefulness for the regime and was becoming more and more of a burden. The Islamic Republic still faced enormous challenges including staggering unemployment, deplorable urban living conditions and an altogether stagnant economy. Increasing US involvement was also raising the stakes of the war. In 1986, moreover, the price of a barrel of oil drastically fell from \$28 US to \$10 US. By 1988 it had only recovered by 8 US dollars. This decline undoubtably put great additional strain upon both regimes. In the summer of 1988 Iran agreed to abide by Resolution 598 of the UN Security Council which included inter alia an immediate ceasefire, provisions for a UN observer force, an immediate release of prisoners of war and the establishment of an 'impartial body' to decide upon the responsibility of the war.

On the whole for Iraq, the last year of the war had brought a sharp turn-around. Throughout the first half of 1988 Iraq launched new offensives against Iran and occupied more of its territory. Hussein was reluctant to end the war in 1988, and the Ba'thi regime was attempting to sabotage the ceasefire efforts. Even with the Iranian agreement to abide by the framework set out in UN resolution 598, Iraq continued to prosecute the war. In the end however, undoubtedly in the face of mounting international pressure, the steep yearly cost of the war, further declines in oil revenues and the potential for a second Iranian reversal, Hussein reluctantly accepted UN resolution 598 as a basic working framework. On August 20, 1988 the United Nations Iran-Iraq Military Observer Group (UNIIMOG) went into operation along much of the 1,170 kilometre common border between the two countries.

Ten years after the initial Iraqi invasion numerous outstanding issues plagued the pursuit of any permanent official peace between the two countries. Although the fighting had ceased, Iraq, for its part, continued to occupy about 1,600 square kilometres of Iranian territory. The apparently unsolvable disagreement with respect to the Shatt al-Arab waterway remained, with Iran calling for a return to the terms of the 1975 Algiers Accord and Iraq continuing to favour full sovereignty of the channel. Important differences also continued with respect to the nearly 100,000 prisoners of war held between the two countries. On the diplomatic front, four rounds of official negotiations culminated in face to face meetings between the foreign ministers of Iran and Iraq in the summer of 1990. These exchanges appear to have laid the foundations for a summit between Hashemi 
Rafsanjani of Iran and Saddam Hussein of Iraq in order to negotiate a permanent peace between the two countries.

\section{PART IV: CONCLUSION}

From the perspective of its length, its human and material tolls and its sensational practices including chemical warfare and human-wave assaults, the Iran-Iraq war stands as the Third World's War I. The war was largely a local affair. It was fought between two regimes resting uneasily upon deeply fractured societies. In a significant manner the war was the product of conflicting social forces unleased by the gradual insertion of Iran and Iraq into the world economy. This is not to suggest that the war was inevitable in the sense that individual intervention played little or no part in the matter. On the other hand, however, it is to suggest that the war was hardly surprising.

The Clausewitzian dictum that 'war is the continuation of politics by other means' must be modified slightly to accommodate this crucial socio-political dimension. As a result war becomes 'the continuation of domestic politics by other means'. Conventional analysis into war and conflict resolution tends to overlook the pivotal importance of the socio-political dimension. This paper has demonstrated that undulations among social forces in each society were largely responsible for the heightened tensions between Iran and Iraq in the late 1970s. Internal political conflict rooted in fundamental social divisions created new issues of contention between the two states and resurrected older conflicts. These intense political struggles arising from the wider social canvases in Iran and Iraq certainly increased the likelihood that the war would be politically advantageous for the ruling regimes. Indeed, in September of 1980 Iraq exercised its military option for political gain. And the same social and political struggles were also responsible for the prolonged course of the fighting. Third party intervention was fruitless until the regimes were ready to end the fighting, but as long as the war brought forth considerable political advantage it would be tolerated and even encouraged.

Through this modification of the Clausewitzian dictum, moreover, we can begin to appreciate the social costs of the Iran-Iraq war. The concern with barrels/per/day, GNPs or even body counts occludes the startling social costs associated with the war. Both regimes sharpened their repressive capacities and deftly manipulated themes of social unity in order to overcome the deep cleavages in their societies. The social power of oppressed classes and groups waned considerably while their political expressions were thoroughly extirpated. The fruits of the Iran-Iraq war unequivocally accrued to the regimes conducting it. The extent to which we see these social dynamics reproduced in other Third World regions may foretell the outbreak of equally devastating wars, but wars whose spoils should be exclusively measured in terms of gains and losses of the oppressed classes and groups within these societies. 
YCISS Working Papers to March 1991.

\#1. Gorbachev's Arms Control Policy in the Asian Pacific Region: A New Approach? Masahiko Asada, May 1990.

\#2. Regional Security Associations: A New Security Architecture for Non-nuclear Powers. Arnold Simoni, January 1991.

\#3. The Future of Strategy. Michael C. Williams, January 1991.

\#4. The Reflexive Turn and International Relations Theory. Mark Neufeld, January 1991.

\#5. The Social Origins of the Iran-Iraq War. Thom Workman, March 1991.

\#6. How to Measure Military Worth (At Least in Theory). Barry O'Neill, March 1991.

\#7. Why a Good Verification System Can Give Ambiguous Evidence. Barry O'Neill March 1991. 